\title{
Types of traumatic dental injuries to the primary dentition and the surface against which they occurred
}

\author{
Estudo retrospectivo dos tipos de traumatismos dentários na \\ dentição decídua e as superfícies contra as quais esses ocorreram
}

\author{
Linda Patricia CASTILLO SÁNCHEZ ${ }^{1}$ iD 0000-0003-0440-2843 \\ Márcia Rejane Thomas Canabarro ANDRADE² iD 0000-0003-2165-7784 \\ Gabriela Caldeira Andrade AMERICANO ${ }^{3}$ iD 0000-0001-8164-6572 \\ Laís Rueda CRUZ ${ }^{4}$ iD 0000-0002-3417-5250 \\ Mirian de Waele Souchois DE MARSILLAC ${ }^{4}$ (D) 0000-0002-4452-7336
}

Vera CAMPOS ${ }^{4}$ iD 0000-0002-5355-6999

\section{ABSTRACT}

Objectives: The aims of this retrospective study were to investigate the types of traumatic dental injury recorded in an oral health service within a ten-year period and to report the type of surface against which the traumatic dental injury occurred. Methods: Dental records from children assisted in the Dental Trauma Clinic at the Rio de Janeiro State University's School of Dentistry, between 2006 and 2016, were analyzed. Only those records who had registered some type of trauma in the primary anterior teeth (incisors and canines) and aged 0-96 months at the time of trauma were considered eligible for the study. Results: Four hundred and eightythree dental records were included, totalizing 786 traumatized teeth. The average age when traumatic dental injury occurred was 37.25 months $( \pm 18.62)$. Enamel fractures (32.8\%) and intrusive luxations (45.6\%) were the most prevalent types of trauma. The majority of traumas occurred against ceramic surfaces (34\%). The greatest number of teeth with lateral luxation were the ones that hit against a ceramic surface ( $p=0.014$; $U$ Mann-Whitney test). According to this study, the most prevalent type of trauma in the dental tissue and pulp was enamel fracture and in the periodontal tissue was intrusive luxation. The majority of traumas occurred due to falls, at home and against ceramic surfaces. Conclusion: The results showed that a high frequency of the lateral luxation was associated to a traumatic impact against ceramic surfaces.

Indexing terms: Child. Tooth, deciduous. Tooth injuries.

$\boldsymbol{\nabla} \mathbf{\nabla} \boldsymbol{\nabla}$

1 Universidade de Nova lorque, Rad's Children Hospital. Diego, CA, EUA.

2 Universidade Federal Fluminense, Instituto de Saúde de Nova Friburgo, Curso de Odontologia, Departamento de Formação Específica. Nova Friburgo, RJ, Brasil.

${ }^{3}$ Centro Universitário Católico Leste de Minas - Unileste, Faculdade de Odontologia, Departamento Infantil. Ipatinga, MG, Brasil.

4 Universidade do Estado do Rio de Janeiro, Faculdade de Odontologia, Departamento de Odontologia Preventiva e Comunitária. Boulvard 28 de setembro, 157, sala 226, Vila Isabel, 20551-030, Rio de Janeiro, RJ, Brasil. Correspondência para / Correspondence to: MWS de MARSILLAC. E-mail: <mwsm36@hotmail.com>.

$\boldsymbol{\nabla} \boldsymbol{\nabla} \boldsymbol{\nabla}$

How to cite this article

Castillo Sánchez LP, Andrade MRTC, Americano GCA, Cruz LR, De Marsillac MWS, Campos V. Types of traumatic dental injuries to the primary dentition and the surface against which they occurred. RGO, Rev Gaúch Odontol. 2019;67:e20190053. http://dx.doi.org/10.1590/1981-8 6372019000533643 


\section{RESUMO}

Objetivos: Investigar de forma retrospectiva os tipos de traumatismo alveolodentário ocorridos em um atendimento de saúde bucal durante um período de dez anos e relatar os tipos de superfícies contra as quais os traumatismos ocorreram. Métodos: Foram selecionados prontuários de crianças atendidas na Clínica de Traumatismo Dentário na Faculdade de Odontologia da Universidade Estadual do Rio de Janeiro, entre os anos de 2006 e 2016. Os prontuários considerados elegíveis para esse estudo foram os das crianças que possuíam algum tipo de traumatismo em dentes anteriores na dentição decídua (incisivos e caninos) e tinham de 0-96 meses de idade. Resultados: Foram incluídas no estudo 483 prontuários com um total de 786 dentes acometidos por traumatismos. A média de idade em que os traumatismos ocorram foi de 37,25 meses (\$18.62). As fraturas de esmalte (32,8\%) e as luxações intrusivas (45,6\%) foram os tipos de trauma mais prevalentes. A maioria dos traumatismos ocorreu contra superfícies de cerâmica (34\%). A luxação lateral foi o único tipo de traumatismo que apresentou associação com a superfície de impacto, no caso a cerâmica ( $p=0.014 ;$ Teste U de Mann-Whitney). De acordo com o presente estudo o tipo mais prevalente de trauma no tecido dentário e polpa foi a fratura de esmalte e no tecido periodontal foi a luxação intrusiva. A maioria dos traumatismos alveolodentarios ocorreu devido a quedas em suas próprias residências e contra superfícies de cerâmica. Conclusão: Os resultados demonstraram que a alta frequência de luxações laterais está associada ao impacto do traumatismo contra superfícies de cerâmica.

Termos de Indexação: Criança. Dente decíduo. Traumatismos dentários.

\section{INTRODUCTION}

Traumatic dental injury (TDI) is considered a public health problem due to its high prevalence, occurrence at a young age, long-term involvement of the child and caretakers and costs due to follow-ups. According to the same author, one third of all preschool children have suffered at least one TDI [1].

Dental traumas happen mostly in children between 1 and 3 years of age [2-4]. The greatest part of traumas takes place at children's homes and mainly due to falls [5-7]. In the primary dentition, the most common type of trauma in the dental tissue and pulp is crown fracture [8$10]$, and in the periodontal tissue are intrusive luxations and avulsions [11-13].

The severity of TDls depends on the impact strength [14]. This force can be determined by some properties of objects against which teeth hit, such as: mass, velocity, and resiliency [15]. Therefore, besides the knowledge of aetiology, place and moment of the accident [16], the type of surface against which teeth hit can also help dentists in the diagnosis and in the treatment. Studies have considered homes, schools, streets as places of accidents [4,17], however none of them have reported types of surfaces.

Until this moment, dental literature does not address studies on surfaces involved in traumatic injuries. Through this notion, preventive protocols can be improved in order to decrease the negative effects of these injuries to the primary and the permanent dentition. Sequels can occur to both primary and permanent dentitions $[18,19]$. TDIs could be considered to be ranked to the fifth position when considered acute/chronic diseases and injuries worldwide [19].
The aim of this retrospective study was to determine the prevalence of types of TDIs in primary anterior teeth and surfaces where traumas have occurred, as well as, to verify the existence of association between types of TDIs and surfaces.

\section{METHODS}

This study was approved by the Ethics Committee for research of the Pedro Ernesto University Hospital (Number of the approved protocol: 748-CEP/HUPE). All guardians signed an informed consent form.

Dental records from children assisted in the Pediatric Dental Trauma Clinic in the Rio de Janeiro State University (UERJ), between 2006 and 2016, were investigated. All children who are referred to the UERJ dental school due to a TDI attend this clinic. In this study only those dental records from children who had some TDI in the primary anterior teeth (upper and/or lower incisors and canines). Anterior teeth are most affected by TDI. The aged 0 to 96 months at the time of trauma were considered eligible for the study. Petti et al. [19] have recently published a metaanalysis in TDI worldwide in children and adults. Their results showed that the prevalence in primary dentition was $22.7 \%$ and in the permanent dentition on 12-year-olds children, the prevalence was $18.1 \%$.

All patients were submitted to clinical and radiographic exams by undergraduates and supervised by a pedodontic teacher. Follow up visits were scheduled based on Malgren et al. [20], which state that successors require monitoring until the crowns' full eruption. Data 
related to patients and TDIs, such as: age, gender, place and surface where traumas have occurred, aetiology as well as types of TDI were extracted from dental records, hence characterizing a retrospective study.

When a child had more than one type of TDI on the same tooth, the most severe one was considered for analysis. The following increasing order of severity was established by the authors to classify dental injuries: enamel cracking, concussion, subluxation, enamel fracture, crown fracture without pulp exposure, lateral luxation, crown fracture with pulp exposure, extrusive luxation, crown-root fracture without pulp exposure, root fracture, intrusive luxation, crown-root fracture with pulp exposure and avulsion. This severity order of dental injuries was established in order to simplify analyses when the tooth had more than one TDI.

Data were processed using SPSS software (SPSS Inc., Chicago, USA). Descriptive analysis and association between variables were accomplished. Kruskal-Wallis and U Mann-Whitney tests were used to verify the association between types of TDIs and types of surfaces. The level of significance was set at 95\%.

The present study was carried out in compliance with ethical principles contained in the Declaration of Helsinki (2000), as well as with the compliance of Brazil's specific legislation.

\section{RESULTS}

Thirteen of the 496 dental records of children with TDI to the primary dentition were excluded because they did not have enough required information. Therefore, 483 dental records were included in this study, totalizing 786 traumatized primary anterior teeth.

Among included children, 240 (49.7\%) were boys and $243(50.3 \%)$ girls. The average age of the children at the time of trauma was 37.25 months $( \pm 18.62)$, ranging from 6 to 96 months of age. Table 1 shows the number of children according to age group.

The average number of primary anterior teeth with trauma for each child was $1.62( \pm 0.67)$, ranging from 1 to 3 affected teeth per patient.

Distribution of the frequency of TDIs' and TDIs' aetiology by age group, the greatest part of TDIs happened due to falls (83.2\%), occurred at children's homes $(71.2 \%)$ (table 2) and against ceramic surfaces (34\%), cement (28.5\%) and wood (11.2\%) (table 3).

The number of affected teeth for each type of TDI is described in table 4 . The most prevalent type of trauma in the dental tissue and pulp was enamel fracture (32.8\%) and in the periodontal tissue was intrusive luxation $(45.6 \%)$.

Tables 5 and 6 show the association between types of TDIs and the three most frequent surfaces where traumatic injuries occurred. There was no association between the types of traumas in the dental tissue and pulp and the types of surfaces (table 5). We observed a statistical difference between the average number of teeth that suffered lateral luxation and the types of surfaces ( $p=0.030$; Kruskal-Wallis test) (table 6). Besides that, there was a positive association between lateral luxations and ceramic surfaces ( $p=0.014$; U Mann-Whitney test).

Table 1. Distribution of the number of children by age group. Rio de Janeiro (RJ), 2006-2016.

\begin{tabular}{|c|c|c|}
\hline Age group & $\mathrm{n}$ & $\%$ \\
\hline $0-12$ & 29 & 6.0 \\
\hline $12-24$ & 118 & 24.4 \\
\hline $24-36$ & 129 & 26.7 \\
\hline $36-48$ & 85 & 17.6 \\
\hline $60-72$ & 36 & 7.5 \\
\hline $72-84$ & 12 & 2.5 \\
\hline $84-96$ & 6 & 1.2 \\
\hline Total & 483 & 100 \\
\hline
\end{tabular}

Note: $\mathrm{n}$ : number of children with some traumatic dental injury in the primary anterior teeth (incisors and/or canines). 


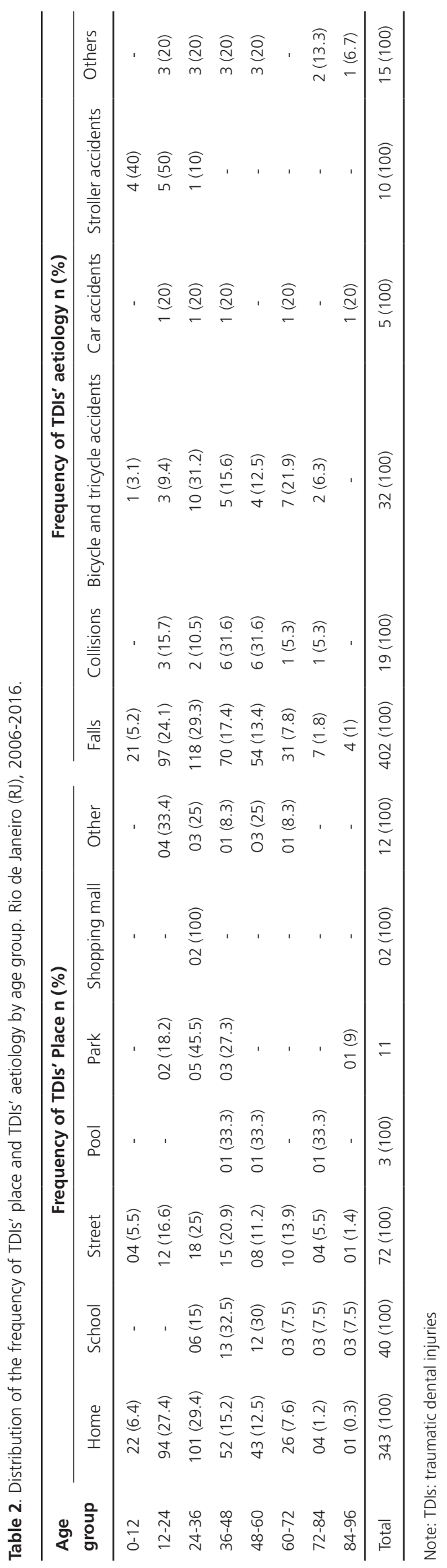


Table 3. Frequency of surface types where TDIs have occurred. Rio de Janeiro (RJ), 2006-2016

\begin{tabular}{|c|c|c|}
\hline Type of surface & $n$ & $\%$ \\
\hline Iron & 22 & 4.6 \\
\hline Soil & 16 & 3.3 \\
\hline Asphalt & 22 & 4.6 \\
\hline Stone & 8 & 1.6 \\
\hline Wood & 54 & 11.2 \\
\hline Marble & 10 & 2.1 \\
\hline Others & 45 & 9.3 \\
\hline
\end{tabular}

Note: TDIs: traumatic dental injuries; n: number of children with some traumatic dental injury in the primary anterior teeth.

Table 4. Distribution of the number of affected teeth to each type of traumatic injury. Rio de Janeiro (RJ), 2006-2016.

\begin{tabular}{|c|c|c|c|}
\hline \multirow{6}{*}{ 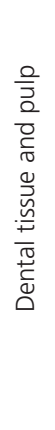 } & Type of TDI & $\mathrm{n}$ & $\%$ \\
\hline & Enamel crack & 1 & 0.5 \\
\hline & Enamel fracture & 66 & 32.8 \\
\hline & Crown fracture with pulp exposure & 30 & 14.9 \\
\hline & Crown-root fracture without pulp exposure & 2 & 1.0 \\
\hline & Total & 201 & 100 \\
\hline \multirow{4}{*}{ 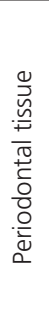 } & Concussion & 21 & 3.6 \\
\hline & Subluxation & 67 & 11.4 \\
\hline & Lateral luxation & 48 & 8.3 \\
\hline & Total & 585 & 100 \\
\hline
\end{tabular}

Table 5. Association between types of TDIs in the dental tissue and pulp and types of surfaces. Rio de Janeiro (RJ), 2006-2016.

\begin{tabular}{|c|c|c|c|c|}
\hline Type of TDI & Wood & Cement & Ceramic & $p$ value* \\
\hline Enamel crack & $0.00 \pm 0.00$ & $0.01 \pm 0.08$ & $0.00 \pm 0.00$ & 0.454 \\
\hline Enamel fracture & $0.04 \pm 0.19$ & $0.14 \pm 0.46$ & $0.19 \pm 0.59$ & 0.284 \\
\hline Crown fracture without pulp exposure & $0.07 \pm 0.26$ & $0.20 \pm 0.58$ & $0.07 \pm 0.29$ & 0.118 \\
\hline Crown fracture with pulp exposure & $0.02 \pm 0.14$ & $0.06 \pm 0.30$ & $0.07 \pm 0.33$ & 0.590 \\
\hline Crown-root fracture with pulp exposure & $0.02 \pm 0.14$ & $0.06 \pm 0.30$ & $0.09 \pm 0.35$ & 0.298 \\
\hline Root fracture & $0.07 \pm 0.43$ & $0.5 \pm 0.37$ & $0.02 \pm 0.17$ & 0.507 \\
\hline
\end{tabular}

Note: *Kruskal-Wallis test; TDI's: traumatic dental injuries; SD: standard deviation. 
Table 6. Association between types of TDIs in the periodontal tissue and types of surfaces. Rio de Janeiro (RJ), 2006-2016.

\begin{tabular}{|c|c|c|c|c|}
\hline Type of TDI & Wood & Cement & Ceramic & $p$ value \\
\hline Concussion & $0.05 \pm 0.23$ & $0.02 \pm 0.19$ & $0.04 \pm 0.28$ & 0.276 \\
\hline Subluxation & $0.20 \pm 0 ., 65$ & $0.10 \pm 0.40$ & $0.14 \pm 0.49$ & 0.650 \\
\hline Lateral luxation & $0.00 \pm 0.00$ & $0.10 \pm 0.46$ & $0.13 \pm 0.42$ & 0.030 \\
\hline Extrusive luxation & $0.05 \pm 0.30$ & $0.15 \pm 0.55$ & $0.05 \pm 0.28$ & 0.191 \\
\hline Avulsion & $0.22 \pm 0.60$ & $0.25 \pm 0.70$ & $0.24 \pm 0.67$ & 0.961 \\
\hline
\end{tabular}

Note: "Kruskal-Wallis test; TDI's: traumatic dental injuries; SD: standard deviation.

\section{DISCUSSION}

Retrospective studies help to develop preventive programs [21], which are necessary to reduce the frequency of TDIs in preschool children [22]. According to a meta-analysis on the incidence and prevalence of TDI worldwide, performed in 2018, this could be a neglected condition in the primary and the permanent dentition. An overall of one billion subjects have had at least one TDI to one of both dentitions [19]. Anterior teeth, including incisors and canines, in children ranging from zero to 8 years of age are most studied in TDI to the primary dentition $[18,23]$.

This study showed that boys and girls were affected equally by traumas in the primary dentition, and this result is consistent with the current literature $[5,6,15,22]$. Some studies $[7,11,21]$ have also reported that the age group of 12-36 months had the highest frequency of TDIs. Most of traumas occurred at the children's homes due to falls $[21,24,25]$. Children among this age group do not have a good motor skill, which hampers them to do precise and safe movements [8], being more susceptible to falls. Besides that, these children spend most of their time at home, which explains the high frequency of traumas at their houses $[4,14,24,25]$. Consumers products associated to TDI in primary dentition up to 4 years of age were mostly related to falls against furniture/fixtures as beds, floor, stairs, tables and chairs. Age group 5 to 9 years old falls were mostly associated to recreation (monkey bars, scooters and swing set) and also to furniture/fixtures [26]. Authors in the present paper believe that the greatest part of TDls occurred against ceramic surfaces, because this is a commonly used material in Brazilian homes.
Studies have also reported that the most prevalent type of trauma in the dental tissue and pulp was enamel fracture and in the periodontal tissue was intrusive luxation $[2,11,27,28]$. This high frequency of intrusive luxations in the primary dentition can be explained by the resilience of the alveolar bones and the elasticity of the periodontal ligament [29]. Periodontal ligament, pulp and tooth fluids are responsible for the teeth's viscoelastic properties and protect the hard dental tissue whenever they are able to disperse the impact strength [30]. The present study showed a statistically significant difference between the average number of teeth that suffered lateral luxation and the types of surfaces, with a positive association with ceramic. One can imagine, based on the literature, that a perpendicular force applied to the tooth's crown can also displace the dental root laterally due to a pliable bone structure at a tender age and the viscoelasticity from the tooth and its periodontal ligament. The statistical analysis employed in this study cannot determine a cause and effect relationship between the different types of surface due to its sample size. It can only point out that lateral luxation had a higher frequency of occurrence when TDI occurred against a ceramic surfaces. Ergo, this is a limitation of the present study.

The type of TDI and its extension depends on the impact strength [14]. This force can be determined by some properties of objects against which teeth hit, such as: mass, velocity, and resiliency. It is well known that the greater the mass and the velocity, as well as, the lower resilience of an object, the greater the impact strength. As in most cases, the houses' floors are hard (i.e. ceramic), teeth absorb large part of the impact strength leading to severe injuries (i.e. luxations). The direction of the impact strength is other relevant factor which 
can affect the severity of injuries. This force occurs in different angles, but most of the time it is applied on the crown's buccal surface in a perpendicular direction to the root long axis leading to crown and/or root fractures [15]. Obviously, all these variables should be taken into consideration when analyzing TDIs and as a retrospective study, they pose as a limitation. Hence, strategies as child proofing the floor at day care centers, children's stores, playgrounds, children's hospitals and home environments might pose as a good alternative to help prevent TDI in young children.

\section{CONCLUSION}

According to this study, the most prevalent type of trauma in the dental tissue and pulp was enamel fracture and in the periodontal tissue was intrusive luxation. The majority of traumas occurred due to falls, at home and against ceramic surfaces. Although many factors are involved in traumas of the primary teeth, the results of this study showed that traumatic impact against ceramic surface was associated with high frequency of the lateral luxation. The harder are the surfaces of floors, more severe are injuries. Therefore, it may be a good strategy to have a softer flooring using more resilient materials at home, in public or private spaces upon which primarily children play or spent most part of their childhood in order to prevent TDI in younger children.

\section{Collaborators}

LP CASTILLO SÁNCHEZ, collected the data, reviewed the literature and wrote the manuscript. MRTC ANDRADE, carried out statistical analysis and contributed to interpretation of the results. GCA AMERICANO, reviewed the literature and wrote the manuscript. LR Cruz, collected the data and reviewed the literature. MWS DE MARSILLAC, reviewed the literature and reviewed the manuscript. $\vee$ CAMPOS, conception and designed the study, prepared and wrote the manuscript and contributed to interpretation of the results.

\section{REFERENCES}

1. Glendor ULF. Epidemiology of traumatic dental injuries: a 12 year review of the literature. Dent Traumatol. 2008;24(4):603-611. https://doi.org/10.1111/j.1600-9657.2008.00696.x
2. Cardoso M, Rocha MJC. Traumatized primary teeth in children assisted at the Federal University of Santa Catarina, Brazil. Dent Traumatol. 2002; 18(3):129. doi: https://doi.org/10. 1034/j.1600-9657.2002.00030.x.

3. Cunha RF, Puglies DMC, Vieira AEM. Oral trauma in Brazilian patients aged, 0-3 years. Dent Traumatol. 2001;17(5):210212. https://doi.org/10.1034/j.1600-9657.2001.170504.x

4. Carvalho V, Jacomo DRES, Campos V. Frequency of intrusive luxation in deciduous teeth and its effects. Dent Traumatol. 2010; 26(4):304-307. https://doi.org/10.1111/j.1600-9657. 2010. 00893.x.

5. Jacomo DRES, Campos V. Prevalence of sequelae in the permanent anterior teeth after trauma in their predecessors: a longitudinal study of 8 years. Dent Traumatol. 2009;25(3):300-4. https://doi.org/10.1111/j.1600-9657.2009.00764.x

6. Kramer PF, Zembruski C, Ferreira SH, Feldens CA. Traumatic dental injuries in Brazilian preschool children. Dent Traumatol. 2003 Dec;19(6):299-303. doi: 10.1111/j.1600-9657.2009. 00852.x

7. Lenzi MM, Jacomo DRES, Carvalho V, Campos V. Avulsion of primary teeth and sequelae on the permanent successors: longitudinal study. Braz Journal of Dent Traumatol. 2011; 2: 80.

8. Granville-Garcia AF, Menezes VA, de Lira PIC. Dental trauma and associated factors in Brazilian preschoolers. Dent Traumatol. 2005 Dec;21(6):320-3. doi: 10.1111/j.1600-9657. 2005.00390.x

9. Elkarmi RF, Hamdan MA, Rajab LD, Abu-Ghazaleh SB, Sonbol $H N$. Prevalence of traumatic dental injuries and associated factors among preschool children in Amman, Jordan. Dent Traumatol. 2015 Dec;31(6):487-92. doi: 10.1111/edt.12183.

10. Ferreira JM, Fernandes de Andrade EM, Katz CR, Rosenblatt A. Prevalence of dental trauma in deciduous teeth of Brazilian children. Dent Traumatol. 2009 Apr;25(2):219-23. https://doi. org/10.1111/j.1600-9657.2008.00754.x

11. Assunção LRDS, Ferelle A, Iwakura MLH, Cunha RF. Effects on permanent teeth after luxation injuries to the primary predecessors: a study in children assisted at an emergency service. Dent Traumatol. 2009;25(2):165-170. https://doi. org/10.1111/j.1600-9657.2008.00759.x

12. Altun C, Cehreli ZC, Guven G, Acikel C. Traumatic intrusion of primary teeth and its effects on the permanent successors: a clinical follow-up study. Oral Surg Oral Med Oral Pathol Oral Radiol Endod. 2009;107(4):493-498. https://doi.org/10. 1016/j.tripleo.2008.10.016

13. Kramer PF, Onetto J, Flores MT, Borges TS, Feldens CA. Traumatic Dental Injuries in the primary dentition: a 15-year bibliometric analysis of Dental Traumatology. Dent Traumatol. 2016; 32(5):341-346. https://doi.org/10.1111/edt.12262

14. Gabris K, Tarjan I, Rozsa N. Dental trauma in children presenting for treatment at the Department of Dentistry for Children and Orthodontics, Budapest, 1985-99. Dent Traumatol. 2001;17(6):103. https://doi.org/10.1034/j.1600-96 57.2001.017003103.x

15. Andreasen JO, Andreasen FM. Textbook and color atlas of traumatic injuries to the teeth. 3 ed. Copenhagen: Mosby; 1994. 
16. Thor ALI. Delayed removal of fully intruded primary incisor through the nasal cavity: A case report. Dent Traumatol. 2002;18(6):287-298. https://doi.org/10.1034/j.1600-9657. 2002.00070.x .

17. Noori AJ, Al-Obaidi WA. Traumatic dental injuries among primary school children in Sulaimani city, Iraq. Dental Traumatol. 2009;25(4):442-446. https://doi.org/10.1111/j.16 00-9657.2009.00791.x

18. Lenzi MM, da Silva Fidalgo TK, Luiz RR, Maia LC. Trauma in primary teeth and its effect on the development of permanent successors: a controlled study. Acta Odontol Scand. 2018; 22:1. https://doi.org/10.1080/00016357.2018.1508741

19. Petti S, Glendor U, Andersson L. World traumatic dental injury prevalence and incidence, a meta-analysis-One billion living people have had traumatic dental injuries. Dent Traumatol. 2018;34(2):71-86. https://doi.org/10.1111/edt.12389

20. Malmgren B, Andreasen JO, Flores MT, Robertson A, DiAngelis $A J$, Andersson L, et al. Guidelines for the management of traumatic dental injuries: 3. Injuries in the primary dentition. Pediatr Dent. 2016; 38: 377. https://doi.org/10.1111/j.1600-9 657.2012.01146.x

21. Colak I, Markovic D, Petrovic B, Peric T, Milenkovic A. A retrospective study of intrusive injuries in primary dentition. Dent Traumatol. 2009;25(6):605-610. https://doi.org/10.11 11/j.1600-9657.2009.00838.x

22. Oliveira LB, Marcenes W, Ardenghi TM, Sheiham A, Bonecker M. Traumatic dental injuries and associated factors among Brazilian preschool children. Dent Traumatol. 2007; 23(2):76-81. https://doi.org/10.1111/j.1600-9657.2005.00413.x

23. de Amorin CS, Americano GCA, Moliterno LFM, de Marsillac MWS, Andrade MRTC, Campos V. Frequency of crown and root dilaceration of permanent incisors after dental trauma to their predecessor teeth. Dent Traumatol. 2018;34(6):401-405. https://doi.org/10.1111/edt.12433

24. Glendor ULF. Aetiology and risk factors related to traumatic dental injuries - a review of the literature. Dent Traumatol. 2009;25(1):19-31. https://doi.org/10.1111/j.1600-9657.2008. 00694.x

25. Skaare $A B$, Jacobsen I. Primary tooth injuries in Norwegian children (1-8 years). Dent Traumatol. 2005;21(6):315-319. https://doi.org/10.1111/j.1600-9657.2005.00362.x

26. Ali B, Lawrence B, Miller T, Swedler D, Allison J. Consumer Products Contributing to Fall Injuries in Children Aged $<1$ to 19 Years Treated in US Emergency Departments, 2010 to 2013: An Observational Study. Glob Pediatr Health. 2019;6:1. https://doi.org/10.1177/2333794X18821941

27. Flores MT. Traumatic injuries in the primary dentition. Dent Traumatol. 2002;18(6):287-298. https://doi.org/10.1034/j.160 0-9657.2002.00153.x

28. Borum MK, Andreasen JO. Sequelae of trauma to primary maxillary incisors. I. Complications in the primary dentition. Endod Dent Traumatol. 1998;14(1): 31-44.

29. Rocha MJC, Cardoso M. Traumatized permanent teeth in Brazilian children assisted at the Federal University of Santa Catarina, Brazil. Dent Traumatol. 2001;17(6):245. https://doi. org/10.1034/j.1600-9657.2001.170601.x

30. Huang HM, Tsai CY, Lee HF, Lin CT, Yao WC, Chiu WT, et al. Damping effects on the response of maxillary incisor subjected to a traumatic impact force: A nonlinear finite element analysis. J Dent. 2006;34(4):261-268. https://doi. org/10.1016/j.jdent.2005.06.007

Received on: 27/7/2018 Final version resubmitted on: 22/1/2019 Approved on: 6/2/2019 